\title{
Getting the wind knocked out of him - Report of a broncho-cutaneous fistula caused by staphylococcal pneumonia, and review of literature
}

\author{
Ravi Manglani ${ }^{1}$, Osama Ahmed, ${ }^{2}$ Shahryar Eshaghian ${ }^{3}$, Riyad Basir ${ }^{3}$ \\ ${ }^{1}$ Division of Pulmonary, Critical Care and Sleep Medicine, Westchester Medical Center, Valhalla NY; ${ }^{2}$ Department of \\ Medicine, Lincoln Medical Center, Bronx NY; 3Division of Pulmonary and Critical Care Medicine, Lincoln Medical \\ Center, Bronx NY, USA
}

\begin{abstract}
A broncho-cutaneous fistula (BCF) refers to the formation of an abnormal fistulous connection between the tracheobronchial tree and the cutaneous surface of skin. A rare occurrence in and of itself, the disease entity may have varied etiologies, and may or
\end{abstract}

Correspondence: Ravi Manglani, Division of Pulmonary, Critical Care and Sleep Medicine, Westchester Medical Center, Macy's Pavilion,

100 Woods road, Valhalla, NY 10595, USA.

Tel. +1.914-493-7000 - Fax: +1.914-493-8130.

E-mail: ravipapu.manglani@wmchealth.org

Key words: Broncho-cutaneous fistula; Staphylococcus aureus; necrotizing pneumonia.

Authors' contributions: Each of the Authors participated in curation of literature, formulation of the manuscript from conception to design, analysis and finished product. Dr. Riyad Basir played a supervisory role, as Senior Author, in the conception of the topic, editing, analysis, revision of intellectual content, and in literature review. The work has been reviewed and approved by all co- authors.

Conflict of interest: The Authors report no conflicts of interests.

Funding: The Authors do not report the receipt of any form of funding for the project.

Ethics approval and consent to participate: No Ethical Committee approval was required for this Case Report by the Department, because this article does not contain any studies with human participants or animals. Informed consent was obtained from the patient included in this study.

Consent for publication: The patient gave his written consent to use his personal data for the publication of this Case Report and any accompanying images.

Received for publication: 12 August 2020.

Accepted for publication: 14 September 2020

${ }^{\circ}$ Copyright: the Author(s), 2020

Licensee PAGEPress, Italy

Monaldi Archives for Chest Disease 2020; 90:1506

doi: 10.4081/monaldi.2020.1506

This article is distributed under the terms of the Creative Commons Attribution Noncommercial License (by-nc 4.0) which permits any noncommercial use, distribution, and reproduction in any medium, provided the original author(s) and source are credited. may not be associated with a broncho-pleural fistula. We describe a case of a young patient who developed a BCF as a complication of a necrotizing pneumonic process, and his subsequent clinical course. In so doing, we review the clinical features of this peculiar disease entity, analyzing the available medical literature similarities in etiology and variations in management strategies described in the literature thus far.

\section{Introduction}

An aberrant connection (fistula) between bronchi and subcutaneous tissue planes is termed a broncho-cutaneous fistula (BCF), and maybe created as a result of a variety of causes or circumstances. When this connection also includes the pleura, it is termed "broncho-pleural fistula". In the medical specialties, some causes that have been implicated in its formation are - ionizing radiation to the area, necrotizing pneumonia, placement of cardiac pacemaker wires, mechanical ventilation and as a consequence of chest tube placement. Thoracic surgeons and other surgical specialties may encounter the entity more frequently, through patient with trauma or as a complication of surgical procedures such as lobectomy. Herein, we describe a young immunocompromised patient who contracted a necrotizing form of staphylococcal pneumonia that resulted in the formation of a broncho-cutaneous fistula, and his subsequent clinical course. The formation of a BCF is rare occurrence, especially as a complication of staphylococcal pneumonia, and consequently, the index of suspicion for it among practicing clinicians is likely low. Prompt diagnosis and management may lead to considerably less morbidity and patient discomfort.

\section{Case Report}

A 43-year-old male presented with fever, malaise and generalized weakness. His history was notable for active intravenous drug use (IVDU), uncontrolled Human Immuno-Deficiency Virus (HIV) infection, diabetes mellitus type 2 and multiple abscesses at prior injection sites. Physical examination was notable for tachycardia 114/min and fever of 101.7 Fahrenheit (38.7 degrees Celsius), with an erythematous left arm, and a normal systemic examination of the cardiac, respiratory and other systems. Laboratory investigations yielded the presence of methicillin sensitive Staphylococcus aureus (MSSA) in blood, on two separate blood cultures. An antibiogram of the isolated organism demonstrated sensitivity to oxacillin, cefazolin and most other antibi- 
otics, except penicillin. The patient was admitted for intravenous antibiotic therapy with cefazolin 2 grams every 8 hours, for treatment of MSSA bacteremia, with the source likely being cellulitis of the left arm. Over the next week, the patient's symptoms responded to therapy, and bacteremia resolved. An echocardiogram did not demonstrate signs of endocarditis, but a new symptom of left sided chest pain, swelling and crepitus emerged. Imaging of the area (Figure 1) revealed a new $3 \mathrm{~cm}$ gas and fluid containing collection in the left pectoralis major muscle. This collection was seen in continuity with a $5 \mathrm{~cm}$ thick walled cavitary mass of the anterior segment of the left upper lobe, which was a new finding, in comparison to his chest film from a few days ago. The two collections were seen in continuity across the first left costochondral articulation. A phlegmon in the base of the neck and the anterior mediastinum with fluid and gas extending to these areas was also suspected. Due to the suspicion of necrotizing soft tissue infection in this high-risk patient, local surgical wound exploration was performed. The muscle planes and tissues were found to be viable, and scant purulent fluid was evacuated, which grew the same organism with similar antibiogram sensitivities to antibiotics. Unfortunately, in the immediate post-operative period, the patient developed worsening subcutaneous emphysema (Figure 2) extending superiorly through the neck into his face, ending in his eyelids and inferiorly, into his abdomen, ending in the scrotal area.

Due to the extent and rapidity of spread, an intercostal percu- taneous pig tail catheter was placed into the cavitary lung lesion (Figure 2C), as it was felt to be the source of the worsening subcutaneous emphysema. The pig tail was attached to low intermittent suction of $-20 \mathrm{~cm} \mathrm{H}_{2} \mathrm{O}$ and a wound vacuum (VAC) dressing was applied to the surgical incision in order to facilitate resolution of subcutaneous emphysema and pneumomediastinum. The patient also received oxygen supplementation to facilitate nitrogen washout and resorption of extraneous air. Over the next 10 days, the patient experienced clinical and radiological resolution of his symptoms (Figure 3). The chest tube and wound VAC dressing was removed, and the patient was discharged to complete a course of long-term antibiotic therapy, with good result (Figure 3).

\section{Discussion}

A BCF is an abnormal fistulous connection between the tracheobronchial tree and the subcutaneous tissue planes and may or may not be associated with a broncho-pleural fistula. Infrequent as it may be, many precipitating causes of BCF have been reported in the literature, such as necrotizing bacterial pneumonia, fungal pneumonia, ionizing Radiation therapy, trauma, mechanical ventilation, as a complication of chest tube placement, pacemaker lead placement and post- surgical lobectomy. The spontaneous contigu-
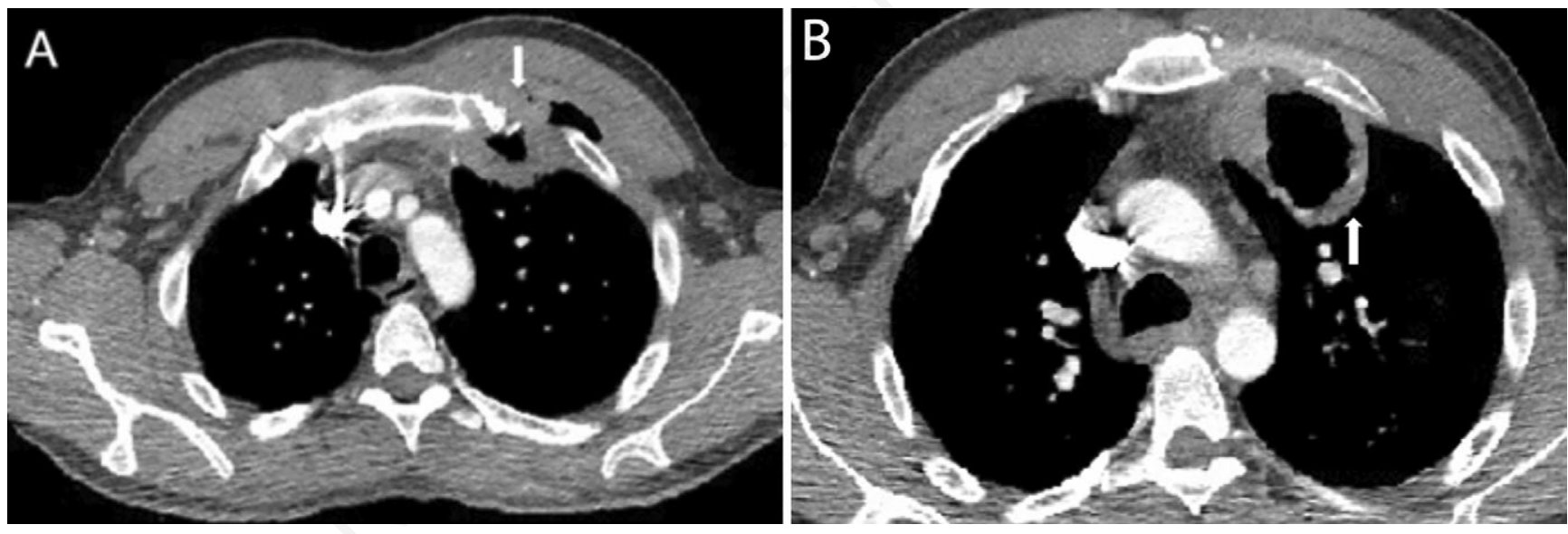

Figure 1. A) Axial cross-sectional images of Computed Tomography of chest, demonstrating air (arrow) tracking across the pectoralis muscle into the subcutaneous tissue planes. B) Axial cross section of CT chest demonstrating left upper lobe cavity (arrow).
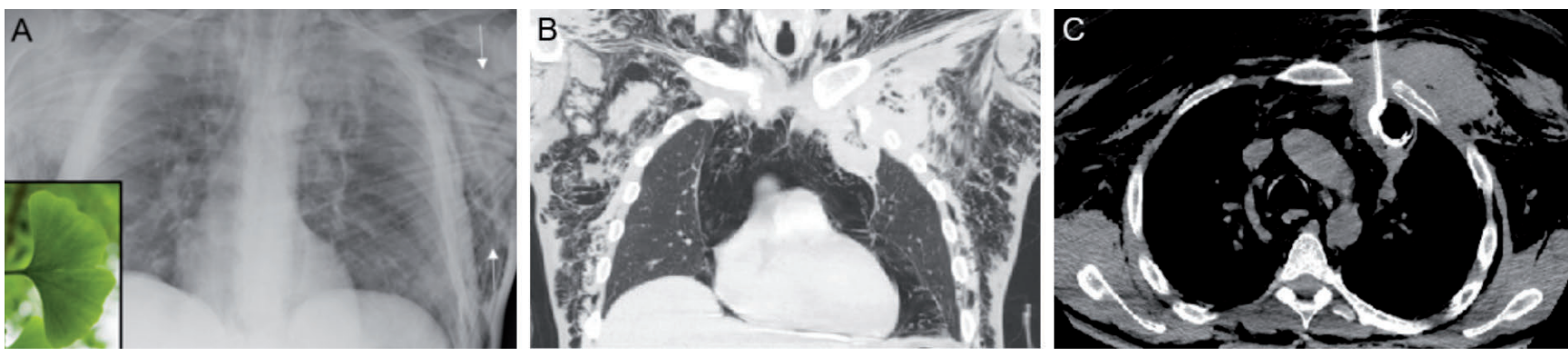

Figure 2. A) Chest $\mathrm{X}$ ray post-surgical wound exploration, demonstrating air(arrows) tracking along muscle fibers of pectoralis major muscle, akin to the "gingko leaf" (inset). B) Coronal reconstruction of Chest CT scan demonstrating extensive subcutaneous emphysema (arrow) and pneumo-mediastinum (star). C) Insertion of intercostal chest tube into cavity. 
ous extension of intrathoracic infection to the skin surface remains a rare cause of a $\mathrm{BCF}$.

In order to form a broncho-cutaneous fistula, at least two prerequisites must be met. First, a direct communication between the broncho-alveolar tissue and the subcutaneous tissue must occur, and second, the pressure within the bronchus must at least transiently exceed the pressure in the subcutaneous tissues, leading to a pressure gradient, along which air can flow out into the subcutaneous tissues [1]. In order to form a BCF without a BPF (and by extension, a pneumothorax), the parietal and visceral pleural surfaces must be adherent to each other, so that the entry of bronchial air into the pleural space is averted.

The diagnosis of a BCF is usually suggested by physical examination findings of swelling and crepitus overlying the affected skin. Interestingly, Krumpe and colleagues [2], in 1981, described a diagnostic sign known as the "bronchial leak squeak"

When a patient with a BCF performs a Valsalva maneuver, bronchial air is forced through the fistula with turbulence, causing an audible "squeak" at the bedside. In so doing, they suggest that variations in the pitch and intensity of the squeak maybe inversely related to the inner diameter of the fistula. Aside from physical diagnostic signs, a common finding on a chest radiograph is the radiolucent striations overlying the area of the pectoralis major muscle, as air under positive pressure tracks along the pectoralis muscle fibers. The radiological sign has been named the "gingko leaf sign", referring to the similarities of the gaseous outlines of muscle fibers of the pectoralis major with the radiating and branching veins of the gingko leaf (Figure 2A). Chest radiology literature has described this as a typical radiological finding of the thoracic polytrauma patient [3]. A pneumomediastinum is suggested by the presence of the "continuous diaphragm sign", where on a Chest radiograph, the central portion of both diaphragms is seen in continuity across the midline.

We performed a PubMed search using the string of terms "broncho-cutaneous fistula" and reviewed the results to identify reports describing the etiologies and management strategies employed to treat these cases. We similarly searched Google Scholar with the same string to capture any publications not indexed in PubMed. The reference lists of pertinent articles identified through this strategy were also screened for possible additional matches. Only English-language publications were extracted. Table 1 summarizes the most salient features of the 25 cases, including the current one, described in available English-language publications.

From the data available (Table 1), it would appear that the disease is commonly associated with ionizing radiation to the chest, as a complication of thoracic surgery and more infrequently, associated with contiguous spread from necrotizing pneumonia. Management strategies have varied widely, with conservative minimally invasive options being favored initially, and more aggressive surgical interventions favored late in the disease course, when symptom burden tends to be heavy. The infrequent nature of this complication precludes any form of organized study of interventions mapped to their respective success rates, resulting in a paucity of evidence-based guidelines and recommendations for the management of this condition. Interventions range from Endobronchial valve placement, chemical pleurodesis, Fibrin glue sealant, Intercostal chest tube placement into the bronchus, to surgical pedicled muscle flap creation and an infra-scapular "blowhole skin incisions" that allows release of air from the subcutaneous tissues.

The role of bronchoscopy in managing a BCF has historically been limited to localization of the culprit bronchus feeding the air leak. Recently, with the advent of novel therapeutic bronchoscopy techniques, pulmonologists are assuming a central role in the management of patients with the condition, especially once conservative measures have failed. The cornerstone of management remains the localization of the bronchial lobe/ segments that contribute to the continued leak of air through the fistula, thus preventing its healing and closure [4]. The technique involves the successive balloon occlusion of the ipsilateral lobe / segmental bronchus, while observing for a decrease in the air leak through the chest tube over the next few breaths. Culprit bronchial segments are not always predictable anatomically (despite the assistance of CT imaging), due to the phenomenon of distal collateral ventilation with neighboring anatomically distinct lobes [5]. On average, 3-4 bronchial segments maybe contributing to the air leak $[4,6]$, and require a measured and deliberate approach in their localization. A digital airflow system connected to the chest tube is a useful adjunct to this process, as relying purely on a decrease in "bubbling" through the chest tube maybe insensitive in determining which bronchial segments contribute significantly to the air leak, aside from having large inter-observer variability.

Once isolated, a variety of bronchoscopic techniques have been utilized to close off the feeding bronchi, including fibrin glue, scle-
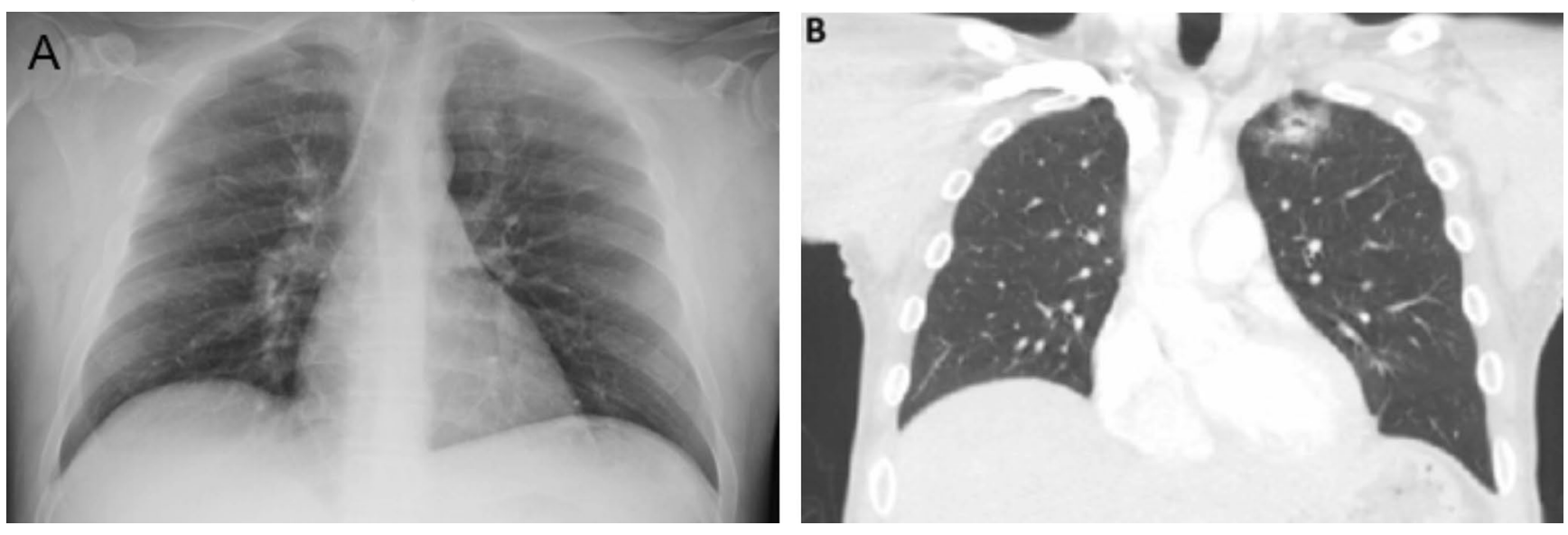

Figure 3. A) Chest $\mathrm{X}$ ray 6 weeks post chest tube and long term intravenous antibiotic therapy. B) Coronal Chest CT set to lung window showing a healing cavitary lesion in the right upper lobe, with resolution of the subcutaneous emphysema and pneumomediastinum. 
Table 1. The most salient features of the 25 cases described in the available English-language publications.

\begin{tabular}{|c|c|c|c|c|c|c|c|c|}
\hline$\#$ & Source & Location & Age/sex & PMHx & Etiology & BPF Y/N & $\begin{array}{c}\text { Management } \\
\text { strategy }\end{array}$ & Outcome \\
\hline 1 & Haubrich [8] & USA & $71 / \mathrm{F}$ & $\begin{array}{l}\text { Squamous cell cancer } \\
\text { lung, local radiotherapy. }\end{array}$ & $\begin{array}{l}\text { Crepitant } \\
\text { pneumococcal } \\
\text { cellulitis }\end{array}$ & $\mathrm{N}$ & $\begin{array}{l}\text { Failed IV antibiotics } \\
\rightarrow \text { Surgical } \\
\text { thoracoplasty } \\
\text { successful }\end{array}$ & Cure \\
\hline 2 & Roberts [9] & UK & $78 / \mathrm{M}$ & $\mathrm{CAD}, \mathrm{s} / \mathrm{p}$ CABG & $\begin{array}{l}\text { Large bore intercostal } \\
\text { chest tube }\end{array}$ & $\mathrm{N}$ & VATS repair & Cure \\
\hline 3 & Patris [10] & Iran & $79 / \mathrm{M}$ & $\mathrm{CAD}, \mathrm{s} / \mathrm{p}$ CABG & Epicardial pacemaker leads & N/A & $\begin{array}{l}\text { Conservative } \\
\text { (IV antibiotics) } \\
\text { due to patient } \\
\text { wishes }\end{array}$ & $\begin{array}{l}\text { Frequent LRTI } \\
\text { and URTI }\end{array}$ \\
\hline 4 & Omori [11] & Japan & $72 / \mathrm{M}$ & $\begin{array}{l}\text { Esophageal cancer, } \\
\text { surgical lobectomy, } \\
\text { endobronchial valve } \\
\text { placement }\end{array}$ & Surgical lobectomy & Y & $\begin{array}{l}\text { Surgical } \\
\text { thoracoplasty }\end{array}$ & No data \\
\hline 5 & Vakil [12] & USA & $52 / \mathrm{M}$ & $\begin{array}{c}\text { Breast cancer, } \\
\text { ternal mesh implantation }\end{array}$ & Sternal mesh infection & $\mathrm{N}$ & $\begin{array}{c}\text { Endobronchial valve } \\
\text { placement after } \\
\text { methylene blue instillation }\end{array}$ & Cure \\
\hline 6 & Bui [13] & USA & $63 / \mathrm{F}$ & Adenocarcinoma lung & Microwave lung ablation & $\mathrm{N}$ & $\begin{array}{l}\text { Conservative } \\
\text { management }\end{array}$ & Cure \\
\hline 7 & Daib [14] & USA & $61 / \mathrm{M}$ & $\begin{array}{l}\text { Pulmonary tuberculosis, } \\
\text { BPF, surgical repair }\end{array}$ & Tuberculosis & Y & $\begin{array}{l}\text { Endobronchial valve } \\
\text { placement }\end{array}$ & Cure \\
\hline 8 & Thivolet [15] & France & $63 / \mathrm{F}$ & $\begin{array}{l}\text { Sarcomatoid breast } \\
\text { cancer }\end{array}$ & Microwave ablation of nodule & $\mathrm{N}$ & $\begin{array}{l}\text { Percutaneous } \\
\text { chest tube in cavity, } \\
\text { fibrin glue }\end{array}$ & $\begin{array}{l}\text { Persistent } \\
\text { pulmonary } \\
\text { cavity, BCF }\end{array}$ \\
\hline 9 & John [16] & USA & $53 / \mathrm{F}$ & $\begin{array}{l}\text { Pneumonia, parapneumonic } \\
\text { effusion }\end{array}$ & Chest tube insertion & $\mathrm{N}$ & $\begin{array}{l}\text { Thoracotomy with } \\
\text { fibrin glue placement }\end{array}$ & Cure \\
\hline 10 & Koh [17] & Singapore & $47 / \mathrm{M}$ & $\begin{array}{l}\text { Pulmonary tuberculosis, } \\
\text { lobectomy }\end{array}$ & Thoracoplasty, Aspergillosis & $\mathrm{Y}$ & $\begin{array}{c}\text { Right mainstem } \\
\text { stenting with omental } \\
\text { path repair }\end{array}$ & Cure \\
\hline 11 & Baildam [18] & UK & 25 weeks $/ \mathrm{N}$ & $\begin{array}{l}\text { Surfactant deficient } \\
\quad \text { lung disease }\end{array}$ & $\begin{array}{l}\text { Mechanical ventilation, } \\
\text { chest compressions }\end{array}$ & $\mathrm{Y}$ & Conservative & Cure \\
\hline 12 & Snell [19] & Australia & $53 / \mathrm{M}$ & Aspergillosis & Lobectomy & $\mathrm{N}$ & $\begin{array}{c}\text { Endobronchial valve } \\
\text { placement }\end{array}$ & Cure \\
\hline 13 & Reich [20] & USA & $33 / \mathrm{M}$ & Diabetes & $\begin{array}{c}\text { Necrotizing Fungal } \\
\text { infection (phycomycetes) }\end{array}$ & $\mathrm{N}$ & $\begin{array}{l}\text { Percutaneous chest } \\
\text { tube placement } \\
\rightarrow \text { Thoracoplasty }\end{array}$ & Passed away \\
\hline & Abu-hijileh [21] & USA & $63 / \mathrm{M}$ & NSCLC, s/p wedge resection & Radiofrequency ablation & Y & $\begin{array}{c}\text { Endobronchial valve } \\
\text { placement }\end{array}$ & Cure \\
\hline 15 & Azuma [22] & Japan & $64 / F \quad B$ & Breast cancer, radiation therapy & Radiation therapy & $\mathrm{N}$ & $\begin{array}{l}\text { Surgical thoracoplasty, } \\
\text { omental flap }\end{array}$ & Cure \\
\hline 16 & Fraser [23] & Canada & $63 / \mathrm{M}$ & Squamous cell Cancer Lung & Radiotherapy & $\mathrm{N}$ & N/A & $\mathrm{N} / \mathrm{A}$ \\
\hline 17 & Radvany [24] & USA & $82 / \mathrm{F}$ & Adenocarcinoma lung & Radiofrequency ablation & $\mathrm{N}$ & $\begin{array}{l}\text { Percutaneous chest tube } \\
\text { into cavity, fibrin sealant }\end{array}$ & Cure \\
\hline 18 & O'Neil [25] & Ireland & $60 / \mathrm{M}$ & NSCLC Lobectomy & Lobectomy & Y & N/A & N/A \\
\hline 19 & Biswas [26] & UK & $45 / \mathrm{M}$ & None & Trauma & $\mathrm{N}$ & Surgical repair & Passed away \\
\hline 20 & Kaur [27] & India & $16 / \mathrm{M}$ & None & $\begin{array}{l}\text { iatrogenic (during } \\
\text { laparotomy for amoebic } \\
\text { liver abscess) }\end{array}$ & $\mathrm{N}$ & Surgical repair & Cure \\
\hline 21 & Marwah28 & India & $25 / \mathrm{M}$ & Tuberculosis & Lobectomy & $\mathrm{N}$ & $\begin{array}{l}\text { Transcutaneous closure } \\
\text { by Duct occlude device }\end{array}$ & Cure \\
\hline 22 & Isomura29 & Japan & $34 / \mathrm{M}$ & Large cell lung cancer Co & ontiguous spread of malignancy & $\mathrm{N}$ & Conservative & N/A \\
\hline 23 & saad30 & Saudi Arabia & $60 / \mathrm{F}$ & Diabetes, CKD & Necrotizing fungal infection & $\mathrm{N}$ & $\begin{array}{l}\text { Conservative management } \\
\text { (poor general condition) }\end{array}$ & $\begin{array}{l}\text { Persistent } \\
\text { fistula }\end{array}$ \\
\hline 24 & Virgilio31 & Italy & $55 / \mathrm{F}$ & $\begin{array}{l}\text { Hydatid cyst removal } \\
\text { by laparotomy }\end{array}$ & Contiguous extension & $\mathrm{N}$ & $\begin{array}{c}\text { Conservative, anthelminthic } \\
\text { agents }\end{array}$ & $\mathrm{N} / \mathrm{A}$ \\
\hline 25 & Current case & USA & $47 / \mathrm{M}$ & Diabetes, IV drug abuse & $\begin{array}{c}\text { Contiguous spread } \\
\text { of necrotizing pneumonia }\end{array}$ & $\mathrm{N}$ & $\begin{array}{l}\text { Percutaneous chest tube } \\
\text { placed into cavity }\end{array}$ & Cure \\
\hline
\end{tabular}

PMHx, past medical history; IV, intravenous; CAD, coronary artery disease; CABG, coronary artery bypass grafting; VATS, video assisted thoracoscopic surgery; BPF, broncho-pleural fistula; N/A, not available. 
rosant agents and implants, with mixed results [4]. Endobronchial valves have recently benefited from a wider adoption in the management of BPF and BCF [7], as well as their original indication of use, for non- operative lung volume reduction. After patients have responded to the intervention, close follow up in 4-6 weeks is recommended, to assess for the possibility of valve removal [4]. Positive pressure ventilation may exacerbate and/or contribute to the formation of a broncho-cutaneous fistula. When a BCF is suspected, every effort must be taken to avoid positive pressure ventilation during elective operative procedures. Possible options include selective intubation of the contralateral main-stem bronchus for the procedure, or the employment of spontaneous breathing with pressure support ventilation, which may decrease the exposure of positive pressure to the area. Although both conditions are generally benign, cases of airway compromise and hemodynamic compromise have been reported. Airway compromise is usually preceded by dysphonia and a change in voice. Hemodynamic compromise occurs when the pressure outside the major venous vessels in the mediastinum exceeds the relatively lower pressures within them, causing a decrease in venous return, and fall in cardiac output by the Frankstarling mechanism.

In our case, we opted for a conservative approach, with supplemental Oxygen and placement of an intercostal chest tube into the cavity. We initially placed the apparatus on low intermittent suction of $-20 \mathrm{~cm}$ of water, in an effort to evacuate air from the area, allowing antibiotics time to clear the site of infection, allowing wound healing and closure of the fistula. Supplemental oxygen was used to wash out Nitrogen from the proximal airways, to facilitate a gradient along which air in the subcutaneous tissues and mediastinum maybe absorbed. The distal end of the BCF at the exit site from the skin was treated with a wound vacuum dressing to assist in evacuation of air from the subcutaneous tissues. The patient eventually improved, his fistula healed, and was discharged to complete a course of long-term antibiotics.

\section{Conclusions}

A broncho-cutaneous fistula is a rare complication of necrotizing pneumonia, caused by contiguous spread of infection into the subcutaneous planes. Increased awareness of the entity will allow clinicians to anticipate complications early, avoiding diagnostic delays. Techniques to avoid further worsening of the clinical status during episodes that require mechanical ventilation include selective intubation of the contralateral main-stem bronchus, or the use of spontaneous breathing modes on the mechanical ventilator. Clinicians may favor conservative options such as pig-tail insertion and oxygen supplementation initially, with more invasive surgical options indicated with increased symptom burden.

\section{References}

1. Dominguez E, De La Torre C, Sánchez AV, et al. Severe tracheobronchial injuries: our experience. Eur J Pediatr Surg 2015;25:71-6. doi: 10.1055/s-0034-1386642

2. Krumpe P, Finley T, Wong L, Treasure R. The bronchial leak squeak: A new sign for the physical diagnosis of bronchopleurocutaneous fistula. Chest 1981;79:336-9. doi: 0.1378/chest. 79.3 .336

3. Chiarenza A, Esposto Ultimo L, Falsaperla D, et al. Chest imaging using signs, symbols, and naturalistic images: a practical guide for radiologists and non-radiologists. Insights Imaging 2019;10:114. doi: 10.1186/s13244-019-0789-4

4. Lazarus DR, Casal RF. Persistent air leaks: a review with an emphasis on bronchoscopic management. J Thorac Dis 2017;9:4660-70. doi: 10.21037/jtd.2017.10.122

5. Vakil E, Sabath B, Baker C, Vaporciyan AA, Casal RF. Bronchocutaneous fistula without pneumothorax localized with methylene blue and managed with endobronchial valves. Ann Am Thorac Soc 2018;15:992-4. doi: 10.1513/Annals ATS.201802-081CC

6. Gillespie CT, Sterman DH, Cerfolio RJ, et al. Endobronchial valve treatment for prolonged air leaks of the lung: a case series. Ann Thorac Surg 2011;91:270-3. doi: 10.1016/j.athoracsur.2010.07.093

7. Travaline JM, McKenna Jr RJ, De Giacomo T, et al. Treatment of persistent pulmonary air leaks using endobronchial valves. Chest 2009;136:355-60. doi: 10.1378/chest.08-2389

8. Haubrich RH, Keroack MA. Pneumococcal crepitant cellulitis caused by a bronchocutaneous fistula. Chest 1992;101:566-7. doi: 10.1378/chest.101.2.566

Roberts RM, Dhesi B, Amerasekera S, Johnston AM. Bronchocutaneous fistula without pneumothorax after intercostal chest drain placement. Am J Resp Crit Care Med 2016;194:765-6. doi: 10.1164/rccm.201604-0824IM

10. Patris V, Argiriou O, Lama N, et al. Late development of a bronchocutaneous fistula due to an epicardial cardioverterdefibrillator lead. J Tehran Heart Cent 2015;10:106-8.

11. Omori C, Toyama H, Takei Y, et al. Positive pressure ventilation in a patient with a right upper lobar bronchocutaneous fistula: right upper bronchus occlusion using the cuff of a leftsided double lumen endobronchial tube. J Anesth 2017;31:627-30. doi: 10.1007/s00540-017-2336-0

12. Vakil E, Sabath B, Baker C, et al. Bronchocutaneous fistula without pneumothorax localized with methylene blue and managed with endobronchial valves. Ann Am Thorac Soc 2018;15:992-4. doi: 10.1513/AnnalsATS.201802-081CC

13. Bui JT, Gaba RC, Knuttinen MG, et al. Microwave lung ablation complicated by bronchocutaneous fistula: case report and literature review. Semin Intervent Radiol 2011;28:152-5. doi: 10.1055/s-0031-1280654

14. Diab K, Rieger K, Noor A. Endobronchial valve placement for pulmonary tuberculosis-related bronchocutaneous fistula after thoracoplasty. J Bronchology Interv Pulmonol 2020;27:294-6. doi: 10.1097/LBR.0000000000000688

15. Thivolet A, Menassel B, Chatté G, et al. Delayed Bronchocutaneous fistula without pneumothorax following a microwave ablation of a recurrent pulmonary metastasis. Cardiovasc Intervent Radiol 2018;41:340-3. doi: 10.1007/ s00270-017-1797-8

16. John SK, Jacob S, Piskorowski T. Bronchocutaneous fistula after chest-tube placement: A rare complication of tube thoracostomy. Heart Lung 2005;34:279-81. doi: 10.1016/j.hrtlng.2004.10.006

17. Koh MS, Ling Hsu AA, Thirugnanam A. Novel management of a large chronic bronchocutaneous fistula after lobectomy. Interact Cardiovasc Thorac Surg 2005;4:248-9. doi: 10.1510/icvts.2004.101998

18. Baildam EM, Dady IM, Chiswick ML. Bronchocutaneous fistula associated with mechanical ventilation. Arch Dis Child 1993;69:525-6. doi: 10.1136/adc.69.5_spec_no.525

19. Snell GI, Holsworth L, Fowler S, et al. Occlusion of a broncho-cutaneous fistula with endobronchial one-way valves. Ann 
Thorac Surg 2005;80:1930-2. doi: 10.1016/j.athoracsur.2004.06.037

20. Reich J, Renzetti AD. Pulmonary phycomycosis. Report of a case of bronchocutaneous fistula formation and pulmonary arterial mycothrombosis. Am Rev Respir Dis 1970;102:95964. doi: 10.1164/arrd.1970.102.6.959

21. Abu-Hijleh M, Blundin M. Emergency use of an endobronchial one-way valve in the management of severe air leak and massive subcutaneous emphysema. Lung 2010;188:253-7. doi: 10.1007/s00408-009-9204-0

22. Azuma R, Kajita M, Kubo S, Kiyosawa T. Radiation-induced thoracic necrosis with a pulmonary cutaneous fistula repaired using a free omental flap: A case report. BMC Surg 2019;19:14. doi: 10.1186/s12893-019-0479-7

23. Fraser A, Nolan RL. Malignant bronchosubcutaneous fistula presenting as subcutaneous emphysema. J Thorac Imaging 2002;17:319-21. doi: 10.1097/00005382-200210000-00010

24. Radvany MG, Allan PF, Frey WC, et al. Pulmonary radiofrequency ablation complicated by subcutaneous emphysema and pneumomediastinum treated with fibrin sealant injection. Am J Roentgenol 2005;185:894-8. doi: 10.2214/ajr.04.0235

25. O'Neill A, Beddy P. Bronchopleural cutaneous fistula. Am J
Roentgenol 2008;190:W315. doi: 10.2214/AJR.07.3441

26. Biswas S, Guy RJ, Phillips RK. Colo-broncho-cutaneous fistula complicating traumatic diaphragmatic rupture. J R Soc Med 2001;94:88-9. doi: 10.1177/014107680109400213

27. Kaur N, Maheshwari K, Gupta A. Broncho-hepatico-cutaneous fistula in a case of amoebic liver abscess. Trop Doct 2014;44:110-1. doi: 10.1177/0049475513518529

28. Marwah V, Ravikumar R, Rajput AK, Singh A. Transcutaneous closure of chronic broncho-pleuro-cutaneous fistula by duct occluder device. Lung India 2016;33:216-8. doi: 10.4103/ 0970-2113.177440

29. Isomura T, Noguchi M, Murate T, Hasegawa Y. A double fistula, broncho-cavitary-cutaneous communication caused by cancer invasion. Intern Med 2001;40:1238-40. doi: 10.2169/internalmedicine. 40.1238

30. Saad ESA, Fahal AH. Broncho-pleuro-cutaneous fistula and pneumothorax: Rare challenging complications of chest wall eumycetoma. PLoS Negl Trop Dis 2017;11:e0005737. doi: 10.1371/journal.pntd.0005737

31. Virgilio E, Mercantini P, Tarantino G, et al. Broncho-hepatocutaneous fistula of hydatid origin. Surg Infect (Larchmt) 2015;16:358-9. doi: 10.1089/sur.2014.109 